\title{
Coexistence of Non-tuberculosis Mycobacterium and Bronchiectasis at the Region of Bronchoscopic Coil Insertion: A Case Report
}

\author{
Bronkoskopik Olarak Coil Yerleştirilen Bölgede Tüberküloz Dışı \\ Mikobakteri ve Bronşektazi Birlikteliği: Olgu Sunumu
}

Efsun Gonca Uğur Chousein, Elif Tanrıverdi, Demet Turan, Zeynep Yıldırım, Mustafa Çörtük, Halit Çınarka, Mehmet Akif Ozgul, Erdoğan Çetinkaya

\begin{abstract}
Novel treatments are needed for chronic obstructive pulmonary disease (COPD), and particularly for severe emphysema, which is one of the leading causes of morbidity and mortality and is responsible for high global health costs. One promising treatment is bronchoscopic lung volume reduction (BLVR), with coils or valves selected according to the patients' radiological and functional status. Since being accepted as a new treatment, early complications of BLVR procedures in the form of pneumonia, pneumonitis, pneumothorax, hemorrhage, respiratory failure and cardiac arrest have become better known, while late complications are less known. We discuss here a patient diagnosed with a lower respiratory tract infection due to a non-tuberculous mycobacterium (Mycobacterium abscessus) at a newly developed bronchiectasis site, 2 years after BLVR with a coil, as the first case report of such a complication. Bronchoscopic lung volume reduction is a promising treatment for severe emphysema, but patients should be evaluated for long-term complications aside from those occurring in the early period.
\end{abstract}

Key words: COPD, bronchoscopic volume reduction, non-tuberculous mycobacterium, bronchiectasis.

\section{Özet}

Dünyada önde gelen ölümlere ve yüksek küresel sağlık giderlerine neden olan kronik obstrüktif akciğer hastalığı (KOAH), özellikle şiddetli amfizem için yeni tedavilere ihtiyaç vardır. Bu konuda umut vaat eden tedavilerden biri de hastanın radyolojik ve fonksiyonel durumuna göre seçilen coil veya valfler ile uygulanan bronkoskopik akciğer hacim azaltıcı tedavilerdir (BAHAT). Yeni bir tedavi olarak kabul edildiği için pnömoni, pnömonitis, pnömotoraks, kanama, solunum yetmezliği ve kalp durması gibi işlemin erken komplikasyonları daha iyi bilinirken, geç komplikasyonları daha az bilinmektedir. Bronkoskopik akciğer hacmi azaltıcı tedavi (BAHAT) olarak coil uygulanan bölgede 2 yıl sonra yeni gelişen bronşektatik alanda tüberküloz dışı mikobakteri (Mycobacterium abscessus) üremesi saptanan ve tedavi edilen olgu bu komplikasyonun geliş̧iği ilk olgu olarak sunulmuştur. Amfizem için ümit verici yeni bir tedavi olarak kullanıma giren bronkoskopik akciğer hacminin azaltıcı tedavi; erken dönem komplikasyonlarının yanı sıra geç dönem komplikasyonlar açısından da değerlendirilmeli ve takip edilmelidir.

Anahtar Sözcükler: KOAH, bronkoskopik hacim azaltıcı tedavi, non-tüberküloz mikobakteri, bronşektazi.
Department of Pulmonology, University of Health Sciences Turkey Yedikule Chest Diseases and Thoracic Surgery Education and Research Hospital, İstanbul, Turkey
Sağlık Bilimleri Üniversitesi Yedikule Göğüs Hastalıkları ve Göğüs Cerrahisi Eğitim ve Araştırma Hastanesi, Göğüs Hastalıkları Bölümü, İstanbul

Submitted (Başvuru tarihi): 05.1 1.2020 Accepted (Kabul tarihi): 26.03.2021

Correspondence (iletişim): Efsun Gonca Uğur Chousein, Department of Pulmonology, University of Health Sciences Turkey Yedikule Chest Diseases and Thoracic Surgery Education and Research Hospital, İstanbul, Turkey

e-mail: efsungoncachousein@yahoo.com 
Despite all preventive measures, chronic obstructive pulmonary disease (COPD) is one of the leading causes of mortality, morbidity and high global health costs. Although constituting only a small percentage of COPD patients, patients with severe emphysema require additional effort, and the high economic burden they represent for countries suggest that new treatment strategies are needed, in addition to the basic bronchodilator treatments. Bronchoscopic lung volume reduction (BLVR) is considered a new treatment for patients with severe emphysema who have frequent attacks, despite optimal bronchodilator treatment and very low pulmonary function tests, and has been included in the guidelines on COPD since 2017 (1).

The basic principle of BLVR is to preferentially ventilate healthy lung regions by bypassing less ventilated areas. The treatment includes both reversible and irreversible methods, with valves being the most common reversible method. A one-way valve made of nithinol is used to isolate diseased lung areas and allows for trapped air and secretions to escape from the target lobe, preventing their re-entry. Another method utilizes coils, which are a spiral shaped memory wire made of nithinol placed at the lungs via bronchoscope, allowing for the ventilation of healthy regions, by-passing the areas that are less involved in ventilation and without blockage. Coils improve the pulmonary function parameters, quality of life and exercise capacity of patients (2-4).

Treatment-related complications can limit the beneficial effects of therapy and increase treatment costs. Known early complications of the procedure that are seen relatively frequently are lower respiratory tract infections, pneumonia, acute exacerbations, pneumonitis, pneumothorax requiring tube placement, hemorrhage, hemoptysis, valve migration, valve expectoration, respiratory failure, cardiac arrest and death $(5,6)$. Less is known about late complications, with a review of literature revealing only a case of bronchiectasis (7) and a case in which an aspergilloma infection developed in the lobe in which the coil was placed (8). Infectious complications are especially important because of their high frequency and mortality (9).

We present here a patient diagnosed with a lower respiratory tract infection due to a non-tuberculous mycobacterium (Mycobacterium abscessus) in a newly developed bronchiectatic area, 2 years after undergoing BLVRcoil placement. As is the general practice of our institution, both verbal and written consent were taken from the patient.
We consider this to be the first case report on the coexistence of both bronchiectasis and non-tuberculous mycobacterial infection, and suggest that the potential should be kept in mind.

\section{CASE}

A 64-year-old Caucasian male patient presented with complaints of breathing difficulty and loss of appetite. He had a smoking history of 150 pack years and pre-existing COPD and ischemic heart disease. He had been treated 2 years earlier for COPD/emphysema with coils implanted bilaterally in two separate procedures performed 3 months apart. He had no history of visiting an area known to be endemic for non-tuberculous mycobacteria or a hammam/spa.

He had being undergoing anti-tuberculosis treatment for the past $5 \frac{1}{2}$ months following a presumptive diagnosis of tuberculosis, which was discontinued 15 days prior due to the development of persistent cough and weight loss, and was subsequently referred to our clinic.

A physical examination revealed bilateral expiratory crackles on auscultation. His pulmonary function test results were as follows: 6-minute walk test (6MWT), 150 meters; Forced Vital Capacity (FVC), 2.99 L (83\%); Forced Expiratory Volume 1st second (FEV1), 1 L (37\%); FEV1/FVC, 35\%; Total Lung Capacity (TLC), 8.3 L (132\%); and Residual Volume (RV), 5.31 L (224\%). A pretreatment posteroanterior (PA) chest $X$-ray (Figure 1a) revealed only emphysema. PA X-rays obtained on presentation revealed the metallic images of the coils in the upper zones bilaterally, and infiltration areas around the coil in the upper zone of the left lung (Figure 1b).

A comparison of the patient's chest computerized tomography $(\mathrm{CT})$ with the pretreatment $\mathrm{CT}$ revealed bilateral, newly developed widespread areas of consolidation in proximity to the coils that were more prominent on the left side (Figure 2).

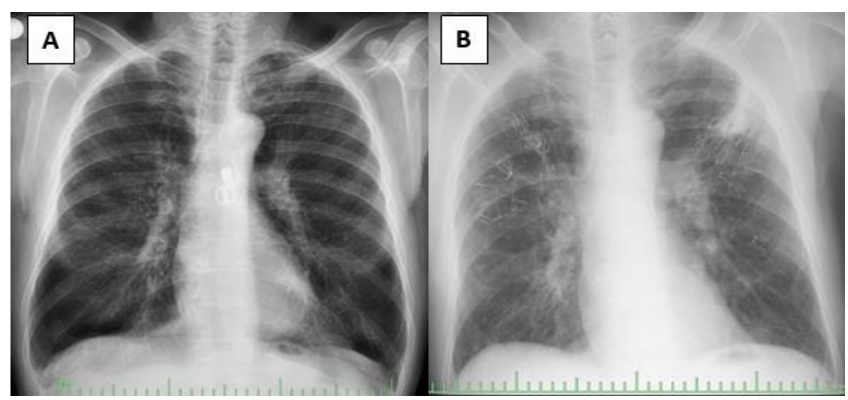

Figure 1a and b: Chest $X$-rays before (a) and 2 years after coil treatment (b) 


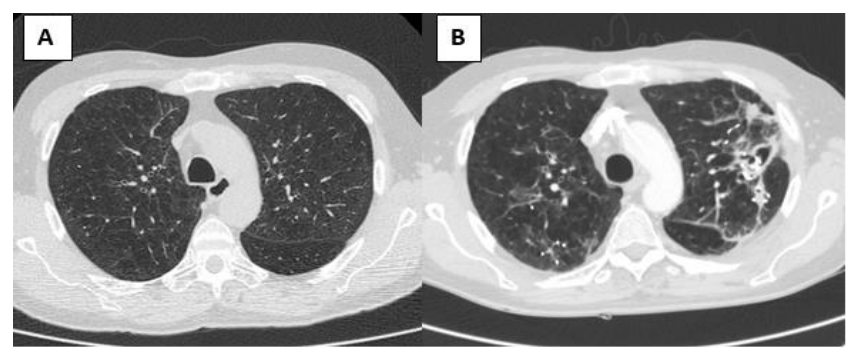

Figure 2a and b: Chest CT showing a previously non-existing (a) consolidation around the coil (b)

The patient's initial three sputum samples were negative for acid-fast bacilli (AFB). The fourth sample was positive and M. abscessus was detected by Tuberculosis Polymerase Chain Reaction (TBC PCR). The patient was treated based on the susceptibility results of the antibiogram with amikacin $2 \times 500 \mathrm{mg}$ (intravenous), moxifloxacin $1 \times 400$ $\mathrm{mg}$ (intravenous), linezolid 2×300 mg (peroral) and clarithromycin $2 \times 500 \mathrm{mg}$ (peroral). The patient was followed through clinical assessment in addition to radiological and bacteriological tests in our center, but requested his follow-up continue in a hospital in his city of residence after completing the first 6 months of follow-up without pharmaceutical and additional procedural side effects.

\section{DISCUSSION}

In recent years, chronic diseases such as chronic obstructive pulmonary disease (COPD) have become a growing medical and economic concern due to the increasing number of patients, mortality and morbidity. Bronchoscopic lung volume reduction (BLVR) treatment modalities in patients with severe emphysema include valves that regulate flow, and coils that act through tissue compression. The goal of these treatments is to bypass hyperinflated lung areas by producing atelectasis in order to render relatively disease-free areas more functional (3).

Early complications of the procedure include lower respiratory tract infections, pneumonia, acute attack, pneumonitis, pneumothorax, hemorrhage, hemoptysis, valve migration, valve expectoration, respiratory failure, cardiac arrest and death $(3,5)$.

COPD acute attacks and lower respiratory tracts infections are common, and can prevent the expected treatment-associated improvement in pulmonary functions. Trudzinski et al. (9) reported identifying potential pathogens, and especially gram negative bacteria, in at least half of the patients treated with BLVR.

Fruchter et al. (10) investigated the potential role of bacterial pathogens isolated before and after BLVR in postprocedural acute attacks.
Aside from these early complications, patients should be evaluated for long-term complications. Being a novel treatment method, there are few studies on its late complications, and there is a need for more studies addressing this subject $(3,6)$.

Sarmand et al. (1 1) observed increased rates of bacterial colonization and long-term changes in the flora following valve implantation.

Coil treatment is reported to be a safe approach, based on the long-term follow-up of patients. In the study by Hartman et al, none of the known late complications such as pneumothorax, coil migration, major hemoptysis, major infections or treatment-related death were encountered. Specimens from patients that later underwent lung transplantation demonstrated that the proximal and medial part of the coil lodges to the subsegmental or segmental airways, provoking an organized fibrotic reaction, while the distal part is engulfed by lung tissue. No significant inflammatory or infectious reaction was observed. These findings are a result of the local tissue pressure, compression and micro-movements of the coil.

Our search of the literature revealed a case of bronchiectasis (7) that developed following BLVR that can be recognized as long term complication (3) and a case with aspergilloma after 3 years (8).

Patients with severe COPD are predisposed for both bronchiectasis and non-tuberculous mycobacterial infections $(12,13)$. Bronchiectasis, COPD and immune suppressive states (anti-TNF therapy, HIV, transplantation etc.) are also known to be predisposing factors for atypical mycobacterial diseases (7).

Berra et al. (14) isolated NTM in 18\% of bronchoscopic samples following BLVR using valves, which needs to be taken into consideration. On the other hand, there are no reported cases of non-tuberculous mycobacterial infection and bronchiectasis confirmed with CT and culture after coil treatment. More studies are needed to assess the usefulness of pre- and post-procedural bacteriologic screening studies.

The initial diagnosis of our patient was severe emphysema. No discernable bronchiectatic areas or sequels that could predispose to bronchiectasis were present in the region where the coils were later inserted on chest radiograms or tomograms prior to the procedure. It was thus concluded that the coils were the causative factor for the development of bronchiectasis. Similarly, according to Debray (7), patient who developed bronchiectasis following coil treatment were considered to have coil injury. 
There are many species of non-tuberculous mycobacteria, one of which, M. abscessus, is found in tap water and soil, and is mostly implicated in wound-associated infections (15). There is no human-to-human transmission, and pulmonary infections are rare (16). The number of patients infected with these pathogens continues to increase. Factors contributing to this are increased awareness among physicians, the larger elderly population, the widespread use of hot water systems, the increased survival of patients with chronic diseases or immune dysfunction, and the more frequent travel to/from tropical regions $(17,18)$. Infections caused by this agent are considerably difficult to treat and there is a lack of consensus on a defined treatment regimen (19).

We believe our patient to be remarkable, being the first documented case of nontuberculous mycobacterial infection following coil placement for BLVR. Although this is a new treatment modality, when evaluating complications, infections should be taken into account, which despite being very well known, may not first come to mind.

\section{CONCLUSION}

With the increasing use of BLVR treatments in recent years, physicians treating and following such patients need to be more vigilant about complications and to evaluate patients who develop complications from a broader perspective. Non-tuberculous mycobacteria should be considered in the differential diagnosis of patients who develop lower respiratory infections following BLVR treatments with coil placement.

\section{CONFLICTS OF INTEREST}

None declared.

\section{AUTHOR CONTRIBUTIONS}

Concept - E.G.U.C., E.T., D.T., Z.Y., M.Ç., H.Ç., M.A.O., E.Ç.; Planning and Design - E.G.U.C., E.T., D.T., Z.Y., M.Ç., H.Ç., M.A.O., E.Ç.; Supervision E.G.U.C., E.T., D.T., Z.Y., M.Ç., H.Ç., M.A.O., E.Ç.; Funding - D.T.; Materials - Z.Y.; Data Collection and/or Processing - M.A.O.; Analysis and/or Interpretation M.Ç., H.Ç.; Literature Review - Z.Y., D.T.; Writing E.G.U.C., E.Ç.; Critical Review - E.Ç., M.A.O.

\section{YAZAR KATKILARI}

Fikir - E.G.U.C., E.T., D.T., Z.Y., M.Ç., H.Ç., M.A.O., E.Ç.; Tasarım ve Dizayn - E.G.U.C., E.T., D.T., Z.Y., M.Ç., H.Ç., M.A.O., E.Ç.; Denetleme - E.G.U.C., E.T., D.T., Z.Y., M.Ç., H.Ç., M.A.O., E.Ç.; Kaynaklar - D.T.;
Malzemeler - Z.Y.; Veri Toplama ve/veya İşleme M.A.O.; Analiz ve/veya Yorum - M.Ç., H.Ç.; Literatür Taraması - Z.Y., D.T.; Yazıyı Yazan - E.G.U.C., E.Ç.; Eleştirel İnceleme - E.Ç., M.A.O.

\section{REFERENCES}

1. Vogelmeier CF, Criner GJ, Martinez FJ, Anzueto A, Barnes PJ, Bourbeau J, et al. Global strategy for the diagnosis, management, and prevention of chronic obstructive lung disease 2017 report GOLD executive summary. Am J Respir Crit Care Med 2017; 195:557-82. [CrossRef]

2. Rabin AS, Keyes CM, Oberg CL, Folch EE. Emerging interventional pulmonary therapies for chronic obstructive pulmonary disease. J Thorac Imaging 2019; 34:248-57. [CrossRef]

3. Hartman JE, Klooster K, Gortzak K, Hacken NHT, Slebos DJ. Long - term follow - up after bronchoscopic lung volume reduction treatment with coils in patients with severe emphysema. Respirology 2015; 20: 319-26. [CrossRef]

4. Sciurba FC, Criner GJ, Strange C, Shah PL, Michaud G, Connolly TA, et al. Effect of endobronchial coils vs usual care on exercise tolerance in patients with severe emphysema: The RENEW randomized clinical trial 2016; JAMA 24-31;315(20):2178-89. [CrossRef]

5. Daniel Franzen D, Straub G, Lutz Freitag L. Complications after bronchoscopic lung volume reduction. J Thorac Dis 2018;10: 2811 -5. [CrossRef]

6. Kontogianni K, Gerovasili V, Gompelmann D, Schuhmann M, Heussel C.P, Herth F.J.F, et al. Effectiveness of endobronchial coil treatment for lung volume reduction in patients with severe heterogeneous emphysema and bilateral incomplete fissures: a six-month follow-up. Respiration 2014; 88:52-60. [CrossRef]

7. Debray MP, Marceau A, Dombret MC, Bunel V, Leroy S, Deslée $G$, et al. Bronchiectasis complicating lung volume reduction coil treatment. Chest 2017; 152:57-60. [CrossRef]

8. Plante A, Guinde J, Boudreau C, Maltais F, Martel S, Delage $A$, et al. A rare complication: development of an aspergilloma after endobronchial coil placement in a COPD patient. Respiration 2020; 99:423-25. [CrossRef]

9. Trudzinski FC, Seiler F, Wilkens H, Metz C, Kamp A, Bals $R$, et al. Microbiological airway colonization in COPD patients with severe emphysema undergoing endoscopic lung volume Reduction. Int J Chron Obstruct Pulmon Dis 2017; 13:29-35. [CrossRef]

10. Fruchter $O$, Rosengarten D, Goldberg E, Ben-Zvi H, Tor R, Kramer MR. Airway bacterial colonization and serum C-reactive protein are associated with chronic obstructive 
pulmonary disease exacerbation following bronchoscopic lung volume Reduction. Clin Respir J 2016; 10:239-45. [CrossRef]

11. Sarmand N, Gompelmann D, Kontogianni K, Polke M, Herth FJF, Eberhardt R. New bacterial growth in bronchial secretions after bronchoscopic valve implantation. Int J Chron Obstruct Pulmon Dis 2018; 13:565-570. [CrossRef]

12. Char A, Hopkinson NS, Hansell DM, Nicholson AG, Shaw EC, Clark SJ, et al. Evidence of mycobacterial disease in COPD patients with lung volume reduction surgery; the importance of histological assessment of specimens: a cohort study. BMC Pulm Med 2014; 14:124. [CrossRef]

13. Balavoine C, Andréjak C, Marchand-Adam S, Blanc FX. Relationships between COPD and nontuberculous mycobacteria pulmonary infections. Rev Mal Respir 2017; 34:1091-7. [CrossRef]

14. Berra G, Plojoux J, Soccal PM, Janssens JP. Identification of non-tuberculous mycobacteria in COPD patients undergoing lung volume reduction: more frequent than expected? Respiration 2019; 98:279-80. [CrossRef]
15. Behr M, Jarand J, Marras TK. Nontuberculous mycobacteria. In: Menzies D(ed). Canadian tuberculosis standards. 7th ed. Ottawa (ON): Public Health Agency of Canada. 2013; Chapter 11; 273-91.

16. Griffith DE, Aksamit T, Brown-Elliott BA, Catanzaro A, Daley C, Gordin F, et al. An official ATS/IDSA statement: diagnosis, treatment, and prevention of nontuberculous mycobacterial diseases. Am J Respir Crit Care Med 2007; 175:367-416. [CrossRef]

17. Aitken $M L$, Limaye $A$, Pottinger $P$, Whimbey $E$, Goss $C H$, Tonelli MR, et al. Respiratory outbreak of Mycobacterium abscessus subspecies massiliense in a lung transplant and cystic fibrosis center. Am J Respir Crit Care Med 2012; 185: 231-32. [CrossRef]

18. Ratnatunga CN, Lutzky VP, Kupz A, Doolan DL, Reid DW, Field $M$, et al. The rise of non-tuberculosis mycobacterial lung disease. Front Immunol 2020; 11:303. [CrossRef]

19. Inove T, Tsunoda A, Nishimoto E, Nishida K, Komatsubara $Y$, Onoe R, et al. Successful use of linezolid for refractory Mycobacterium abcessus infection: A case report. Respir Med Case Rep 2018; 23: 43-5. [CrossRef] 